\title{
Stock Price dan COVID-19 : Sebuah Studi Perbandingan pada Sektor Perbankan Indonesia
}

\author{
Elliv Hidayatul Lailiyah ${ }^{1}$, Arfiana Dewi ${ }^{2}$, Rita Nataliawati ${ }^{3}$ \\ ${ }^{1}$ Institut Teknologi dan Bisnis Ahmad Dahlan Lamongan \\ Program Studi Manajemen \\ Jalan KH.Ahmad Dahlan No 41 Lamongan, East of Java, Indonesia \\ E-mail: ellivhidayatullailiyah@gmail.com \\ ${ }^{2}$ Institut Teknologi dan Bisnis Ahmad Dahlan Lamongan \\ Program Studi Akuntansi \\ Jalan KH.Ahmad Dahlan No 41 Lamongan, East of Java, Indonesia \\ E-mail: Darfiana26@gmail.com \\ ${ }^{3}$ Institut Teknologi dan Bisnis Ahmad Dahlan Lamongan \\ Program Studi Perpajakan \\ Jalan KH.Ahmad Dahlan No 41 Lamongan, East of Java, Indonesia \\ E-mail: nataliarita588@gmail.com
}

\begin{abstract}
Abstrak
Pandemi COVID-19 mempengaruhi setiap sektor kehidupan termasuk dalam dunia pasar modal dan perbankan. Penelitian ini bertujuan untuk menganalisa peristiwa pandemi COVID-19 terhadap harga saham. Penelitian ini menggunakan studi perbandingan yaitu dengan membandingkan harga saham perbankan kedalam tiga periode. Periode perbandingan yang digunakan adalah sebelum COVID-19 melanda Indonesia, saat awal kasus COVID-19 diumumkan di Indonesia dan pasca kasus awal yaitu ketika vaksin COVID-19 ditemukan pertama kali. Penelitian ini menggunakan bank yang terdaftar di Bursa Efek Indonesia dengan top ten asset terbesar pada kuartal I tahun 2020. Analisis data menggunakan uji Paired Samples T-Test. Hasil penelitian menunjukkan bahwa terdapat perbedaan harga saham sebelum COVID-19 melanda Indonesia dan saat awal kasus COVID-19; terdapat perbedaan harga saham saat awal kasus COVID-19 diumumkan di Indonesia dan pasca kasus COVID-19; serta terdapat perbedaan harga saham sebelum COVID-19 melanda Indonesia dan pasca kasus COVID-19 diumumkan. Kata kunci: Harga Saham, COVID-19, Perbandingan
\end{abstract}

\begin{abstract}
The COVID-19 affects every sector of life, including the capital markets and banking. This study aims to analyze the events of COVID-19 on stock prices. This study compare the stock prices of banks into three periods. The period used is before COVID-19 hit Indonesia, when the initial COVID-19 case was announced in Indonesia and after the initial case, when the COVID-19 vaccine was first discovered. This study uses banks listed on the Indonesia Stock Exchange with the top ten largest assets in the first quarter of 2020. Data analysis uses the Paired Samples T-Test. The results show that there is difference in stock prices before COVID-19 and at the beginning of the COVID-19 case; there is a difference in stock prices when the initial COVID-19 case was announced and after the COVID-19; and there is a difference in stock prices before COVID-19 hit Indonesia and after the COVID-19 was announced.
\end{abstract}

Keywords: Stock Price, COVID-19, Comparison

77 | Jurnal Akuntansi, Ekonomi dan Manajemen Bisnis | Vol. 9 No.1, July 2021, 77-82 | E-ISSN: 2548-9836 


\section{Pendahuluan}

China, negara dimana Novel Coronavirus (COVID-19) pertamakali terdeteksi. COVID-19 diklasifikasikan sebagai pandemi oleh WHO. COVID-19 telah dideklarasikan sebagai pandemi yang merupakan suatu peristiwa emergency yang melanda dunia. Kondisi ini mengartikan bahwa telah terjadi darurat kesehatan internasional. Penyakit yang diakibatkan oleh virus ini adalah yang terkait dengan pernafasan. Selain itu juga menyerang neurologis sistem, hati dan enterik. Tingkat keparahan dari virus ini beragam antara hewan dan manusia (He et al., 2020 ; Zumla et al., 2016). Di Indonesia, dua kasus konfirmasi COVID-19 diumumkan pertama kali pada tanggal 2 Maret 2020, (WHO, 2020).

Pandemi COVID-19 memberikan efek pada pertumbuhan perekonomian di suatu negara. Berdasarkan Internasional Monetary Fund pertumbuhan ekonomi dunia diproyeksikan akan mengalami kontraksi atau tumbuh negatif sebesar 4,9\% pada 2020 (Hafulyon, 2010). Hal ini juga memiliki dampak pada perekonomian Indonesia pada tahun 2020 yang akan bertumbuh negatif (kontraksi) sebesar 0,3 persen. Perlambatan ekonomi Indonesia juga dipengaruhi oleh kebijakan pemerintah dalam menanggulangi penyebaran COVID-19 yaitu kebijakan melakukan social distancing. Kebijakan ini berdampak pada aktvitas masyarakat yang semakin rendah.

Pandemi COVID-19 telah memberikan pengaruh pada setiap sektor kehidupan termasuk dalam dunia pasar modal dan perbankan. Pasar signifikan dipengaruhi secara negatif oleh pandemi (Erdem, 2020). Pasar modal di seluruh dunia mencatat penurunan yang belum pernah terjadi. Penurunan ini lebih besar dibandingkan dengan peristiwa yang sama yaitu wabah penyakit menular yang melanda dunia sebelumnya (Baker et al., 2020). Penelitian dari Arendt \& Mestas (2021) menemukan bahwa terdapat hubungan positif antara jumlah pemberitaan tentang COVID-19 dan sejauh mana penurunan harga saham.

Tekanan COVID-19 juga dialami oleh dunia pasar modal Indonesia. IHSG pada perdagangan pada bulan Maret 2020 mengalami beberapa kali trading halt atau pembekuan sementara perdagangan. Trading halt ini terjadi setelah IHSG turun pada harga 3.937,63 atau turun sebesar 5\%. Sejak awal tahun 2020 trading halt juga mencerminkan penurunan sebesar $36,74 \%$.

Industri perbankan sebagai salah Industri yang berkontribusi besar dalam nilai IHSG di Bursa Efek Indonesia. Salah satu sektor yang tertekan paling dalam pada saat COVID-19 adalah sektor perbankan. Sentimen global adalah yang mempengaruhi kondisi tersebut, yaitu sikap para investor. Sikap ini adalah investor merasa enggan untuk berinvestasi pada asset-aset yang berisiko tinggi dan lebih memilih untuk memegang uang tunai. Selain itu, investor lebih mengkhawatirkan risiko kredit yaitu risiko gagal bayar yang akan menjadi risiko para investor ketika berinvestasi pada sektor perbankan. Investor menjadi lebih pesimis dengan kelangsungan hidup perusahaan dengan tingkat hutang yang tinggi dan sedikit asset (uang tunai) (Ramelli \& Wagner, 2020).

Hal ini semakin memburuk dengan adanya kebijakan lockdown dan social distancing yang membatasi aktivitas masyarakat yang berdampak pada ekonomi yang menurun dan kredit macet yang meningkat. Sehingga saat pandemi COVID-19, bank berfokus untuk meminimalisir gagal bayar dengan membatasi jumlah penyaluran kredit. Kekhawatiran terhadap ketidakpastian dan sentimen pesimis pada pendapatan akan meningkat karena adanya informasi yang efektif (Liu et al., 2020).

Pendapatan terbesar bank berasal dari balas jasa pemberian kredit kepada masyarakat. Hal ini secara tidak langsung mempengaruhi harga saham bank. Apabila jumlah balas jasa pemberian kredit menurun mengakibatkan penurunan jumlah pendapatan bank, sehingga akan menurunkan harga saham bank tesebut. Beberapa saham mengalami koreksi yang cukup besar, seperti saham Bank BCA, Bank BNI, Bank BRI, dan Bank Mandiri mengalami kemerosotan ke angka masing-masing $0,27 \%, 6,81 \%, 6,88 \%$, dan $6,77 \%$.

Pada tanggal 7 September 2020, China telah memperkenalkan vaksin corona untuk pertama kalinya (CNN, 2020). Hal ini mengindikasikan bahwa vaksin 
COVID-19 telah ditemukan. Penemuan vaksin COVID-19 merupakan sentimen yang menjadi penggerak utama pasar keuangan dan pasar modal. Meskipun awal September baru ditemukan vaksin dan belum masuk ke Indonesia tetapi penemuan ini memberikan harapan baru bahwa pandemi akan segera berakhir

Risiko keuangan global meningkat secara substansial sebagai respon terhadap pandemi COVID-19. Begitu pula dengan reaksi pasar saham. Ketidakpastian dari pandemi dan kerugian ekonomi menyebabkan pasar menjadi sangat mudah berubah dan tidak dapat diprediksi (Zhang et al., 2020).

Tujuan penelitian ini yaitu mengetahui pengaruh pandemi COVID-19 pada harga saham sektor perbankan dengan melakukan perbandingan harga saham saat sebelum COVID-19, saat pengumuman pertama kasus konfirmasi COVID-19 dan Pasca pengumuman pertama kasus konfirmasi COVID-19 yang ditandai dengan pengumuman penemuan vaksin pertama kali.

Beberapa penelitian terdahulu Putri (2020), Sumiari dan Putri (2020), Khoiriah et al., (2020), Mangindaan \& Manossoh (2020), dan Wenno (2020) mendapatkan hasil bahwa harga saham sebelum dan sesudah COVID-19 terdapat perbedaan yang signifikan. Penelitian ini menggunakan periode waktu $(\mathrm{t}+1)$ dan menggunakan event pengumuman penemuan vaksin untuk melihat sikap dan reaksi pasar.

\section{Kerangka Pemikiran dan Hipotesis}

Berdasarkan tujuan penelitian maka dapat digambarkan kerangka pemikiran seperti pada gambar1 :

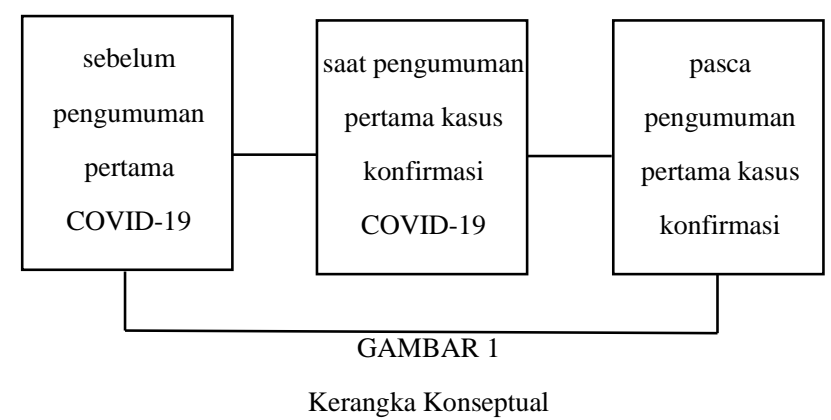

Hipotesis dalam penelitian ini adalah
$\mathrm{H}_{1}=$ Terdapat perbedaan antara harga saham sebelum COVID-19 dan saat pengumuman pertama kasus konfirmasi COVID-19.

$\mathrm{H}_{2}=$ Terdapat perbedaan antara harga saham saat pengumuman pertama kasus konfirmasi COVID-19 dan pasca COVID-19.

$\mathrm{H}_{3}=$ Terdapat perbedaan antara harga saham sebelum COVID-19 dan pasca COVID-19.

\section{Metode}

Penelitian kuantitatif dengan pendekatan deskriptif komparatif merupakan jenis penelitian ini. Data sekunder berupa data closing price harga saham yang digunakan dalam penelitian ini. Closing price yang digunakan pada periode sebelum COVID-19 melanda Indonesia adalah closing price tanggal 03 Januari 2020. Closing price yang digunakan pada periode saat pengumuman kasus konfirmasi COVID-19 adalah closing price tanggal 03 Maret $2020(\mathrm{t}+1)$. Kasus konfirmasi positif COVID-19 terjadi pada 02 Maret 2020. Peneliti menggunakan data $(\mathrm{t}+1)$ untuk melihat reaksi pasar adanya pengumuman. Closing price yang digunakan pada periode pasca pengumuman pertama adalah closing price tanggal 18 Januari 2020. Peneliti menggunakan waktu setelah vaksin COVID-19 (t+1) ditemukan dan diumumkan oleh China dalam menentukan waktu pasca pengumuman pertama kasus COVID-19.

Bank yang terdaftar di Bursa Efek Indonesia dengan top ten asset terbesar pada kuartal I tahun 2020 digunakan sebagai sampel dalam penelitian ini . Top ten bank dengan asset terbesar dipilih karena untuk melihat kemampuan bank dengan asset besar dalam mempertahankan nilai perusahaan yang diproksikan dengan harga saham serta melihat perbedaan reaksi pasar terhadap saham perbankan. Data dianalisis menggunakan uji Paired Samples T-Test dengan bantuan software SPSS.

\section{Hasil dan Pembahasan}

Penelitian ini telah dilakukan uji normalitas dengan menggunakan uji one-sample Kolmogorov-Smirnov Test. Berdasarkan tabel 1, hasil 
uji menunjukkan bahwa nilai Asymp. Sig. (2-tailed) > 0,05. Hal ini menunjukkan bahwa hasil uji berdistribusi normal, sehingga memenuhi untuk melakukan uji Paired Samples T-Test.

TABEL 1.

Hasil dari one-sample Kolmogorov-Smirnov Test.

\begin{tabular}{lc}
\hline & Asymp. Sig. (2-tailed) \\
\hline $\begin{array}{l}\text { Sebelum pengumuman pertama } \\
\text { kasus konfirmasi COVID-19. }\end{array}$ & 0.126 \\
\hline $\begin{array}{l}\text { Saat pengumuman pertama kasus } \\
\text { konfirmasi COVID-19. }\end{array}$ & 0.186 \\
\hline $\begin{array}{l}\text { Pasca pengumuman pertama } \\
\text { kasus konfirmasi COVID-19. }\end{array}$ & 0.062 \\
\hline
\end{tabular}

Sumber : Data diolah (2021)

Tabel 2 merupakan hasil uji Paired Samples T-Test. Pada uji pertama menunjukkan bahwa nilai Sig. (2-tailed) adalah 0,001 <0,05, sehingga hipotesis pertama $\left(\mathrm{H}_{1}\right)$ diterima. Artinya bahwa terdapat perbedaan antara harga saham sebelum COVID-19 dan saat pengumuman pertama kasus konfirmasi COVID-19.

Kondisi ketika pertama kali kasus konfirmasi COVID-19 masuk ke Indonesia menjadi sentimen pesimis bagi dunia pasar modal. Investor cenderung bersikap mencari aman dengan secara aktif menjual saham-saham yang dimilikinya. Hal ini menyebabkan turunnya harga saham dibandingkan dengan saat sebelum kasus COVID-19 masuk ke Indonesia. Fenomena ini menimbulkan reaksi psikologis yaitu kecemasan para investor. Investor juga mengkhawatirkan risiko kredit yaitu risiko gagal bayar yang akan menjadi risiko para investor ketika berinvestasi pada sektor perbankan. Tingginya risiko kredit juga akan berpengaruh terhadap return saham yang akan investor dapatkan. Selain itu, memegang uang tunai akan dirasa lebih menjanjikan dan memberi keamanan pada investor daripada berinvestasi pada asset yang berisiko.

TABEL 2.

Hasil dari Paired Samples T-Test.

\begin{tabular}{|c|c|c|}
\hline & & Sig. (2-tailed) \\
\hline Pair 1 & $\begin{array}{l}\text { Sebelum dan Saat pengumuman } \\
\text { pertama kasus konfirmasi } \\
\text { COVID-19. }\end{array}$ & 0.001 \\
\hline Pair 2 & $\begin{array}{l}\text { Saat dan Pasca pengumuman } \\
\text { pertama kasus konfirmasi } \\
\text { COVID-19. }\end{array}$ & 0.017 \\
\hline Pair 3 & $\begin{array}{lll}\text { Sebelum } & \text { dan } & \text { Pasca }\end{array}$ & 0.000 \\
\hline
\end{tabular}

\begin{tabular}{ll}
\hline pengumuman pertama kasus \\
konfirmasi COVID-19.
\end{tabular}

Sumber : Data diolah (2021)

Pada uji kedua menunjukkan bahwa nilai Sig. (2-tailed) adalah $0,017<0,05$, sehingga hipotesis kedua $\left(\mathrm{H}_{2}\right)$ diterima. Artinya bahwa terdapat perbedaan antara harga saham saat pengumuman pertama COVID-19 dan pasca pengumuman pertama kasus konfirmasi COVID-19.

Kondisi saat pengumuman pertama kasus konfirmasi positif COVID-19 membuat sikap para investor pesimis sehingga saham banyak dijual yang menyebabkan turunnya harga saham. Saat pandemi COVID-19, bank berfokus untuk meminimalisir gagal bayar dengan membatasi jumlah penyaluran kredit. Hal ini adalah akibat buruk adanya kebijakan lockdown dan social distancing. Kebijakan ini membatasi ruang gerak dan aktivitas masyarakat yang berdampak pada ekonomi yang menurun. Banyak masyarakat peminjam (debitur) yang tidak dapat mengembalikan pinjamannya karena kesulitan akibat pandemi COVID-19. Akibatnya kredit macet meningkat.

Penemuan vaksin COVID-19 membawa harapan baru bagi seluruh masyarakat dunia, tidak terkecuali dalam bidang pasar modal. Penemuan vaksin COVID-19 merupakan sentimen yang menjadi penggerak utama pasar keuangan dan pasar modal. Hampir seluruh sektor bersikap positif atas temuan vaksin ini. Sektor perbankan merupakan sektor yang diuntungkan ganda akibat adanya efektifitas vaksin COVID-19. Hal ini dikarenakan perbankan memiliki sifat saham siklus. Artinya, apabila perekonomian berjalan normal kembali, saham di sektor siklus akan lebih diuntungkan daripada sektor lain. Perbankan merupakan saham siklus yang bergantung pada perekonomian sehingga sektor perbankan akan lebih diuntungkan.

Berangsurnya kondisi ekonomi yang membaik membuat sektor perbankan dapat menyalurkan kreditnya, dimana sebelumnya perbankan membatasi penyaluran kredit untuk meminimalisir risiko kredit. Selain itu, kredit-kredit bermasalah dapat berkurang dan pencadangan dapat dikurangi dan laba bersih akan meningkat. Membaiknya kondisi ekonomi membuat

80 | Jurnal Akuntansi, Ekonomi dan Manajemen Bisnis | Vol. 9 No.1, July 2021, 77-82 | E-ISSN: 2548-9836 
para investor bersentimen positif sehingga para investor membeli kembali saham-saham perbankan dan meningkatkan harga saham perbankan.

Pada uji ketiga menunjukkan bahwa nilai Sig. (2-tailed) adalah $0,000<0,05$, sehingga hipotesis ketiga $\left(\mathrm{H}_{3}\right)$ diterima. Artinya bahwa terdapat perbedaan antara harga saham sebelum COVID-19 dan pasca pengumuman pertama kasus konfirmasi COVID-19.

Pada saat vaksin ditemukan, para investor beralih kembali dari produk investasi dengan risiko rendah kepada saham-saham yang potensial seperti perbankan. Pada saat sebelum COVID-19 masuk ke Indonesia perekonomian masih berjalan dengan normal. Berita penemuan vaksin membuat kondisi perekonomian berangsur membaik dikarenakan sentimen pasar yang positif. Walapun demikian, terdapat perbedaan yang signifikan sebelum dan saat vaksin ditemukan. Hal ini dikarenakan terdapat waktu pemulihan akibat dari pandemi COVID-19. Sebagian sektor termasuk perbankan mulai ada peningkatan harga saham tetapi tidak seperti saat sebelum COVID-19 menyerang.

\section{Penutup}

Kesimpulan dari penelitian ini adalah terdapat perbedaan harga saham sebelum COVID-19 melanda Indonesia dan saat kasus pertama COVID-19. Hal ini dikarenakan adanya sentimen negatif dari para investor akan dampak yang timbul akibat COVID-19.

Terdapat perbedaan harga saham saat kasus pertama COVID-19 diumumkan di Indonesia dan pasca COVID-19. Hal ini dikarenakan sentimen positif adanya vaksin COVID-19. Selain itu sektor perbankan juga memiliki sifat saham siklus, dimana saham yang akan menguntungkan apabila perekonomian normal.

Terdapat perbedaan harga saham sebelum COVID-19 melanda Indonesia dan pasca COVID-19 diumumkan di Indonesia. Hal ini dikarenakan perlunya waktu pemulihan akibat adanya pandemi.

Saran dan keterbatasan dari penelitian ini adalah penelitian selanjutnya diharapkan menggunakan variabel lain selain harga saham untuk melihat reaksi pasar. Selain itu, penelitian selanjutnya diharapkan menambahkan jendela waktu lain seperti saat dimana vaksin sudah dilakukan di Indonesia dan pasca vaksinasi nasional. Penelitian selanjutnya diharapkan dapat meneliti sektor lain selain sektor perbankan.

\section{Referensi}

A. Arendt, F., \& Mestas, M. (2021). Coronavirus Disease (COVID-19) Pandemic and Stock Price Crashes: A Cross-National Correlational Approach. Health Communication.

https://doi.org/10.1080/10410236.2020.1871 168

B. Baker, S. R., Bloom, N., Davis, S. J., Kost, K., Sammon, M. C., \& Viratyosin, T. (2020). The Unprecedented Stock Market Impact of COVID-19. Review of Corporate Finance Studies.

C. CNN, I. (2020). china vaksin. https://www.cnnindonesia.com/internasional/ 20200907183557-43-543741/china-pamerka n-vaksin-corona-untuk-pertama-kali

D. Erdem, O. (2020). Freedom and stock market performance during Covid-19 outbreak. Finance Research Letters. https://doi.org/10.1016/j.frl.2020.101671

E. Hafulyon, D. (2010). Perkembangan Ekonomi Global. Juris, 9(2), 133-146. https://doi.org/10.1234/juris.v9i2.912

F. He, F., Deng, Y., \& Li, W. (2020). Coronavirus disease 2019: What we know? Journal of Medical Virology, 92(7), 719-725. https://doi.org/10.1002/jmv.25766

G. Khoiriah, M., Amin, M., \& Kartikasari, A. F. (2020). Pengaruh Sebelum Dan Saat Adanya Pandemi Covid-19 Terhadap Saham Lq-45 Di Bursa Efek Indonesia Tahun 2020. E-Jra, 09(02), 117-126.

H. Liu, H., Manzoor, A., Wang, C., Zhang, L., \& Manzoor, Z. (2020). The COVID-19 outbreak and affected countries stock markets response. International Journal of Environmental Research and Public Health, 17(8), 1-19. 
https://doi.org/10.3390/ijerph17082800

I. Mangindaan Joanne V., \& Manossoh, H. (2020). Analisis Perbandingan Harga Saham PT Garuda Indonesia Persero (Tbk.) Sebelum dan Sesudah Pandemi Covid-19. Jurnal Administrasi Bisnis (Jab), 10(2), 80-85. https://doi.org/10.35797/jab.10.2.2020.31281 $.80-85$

J. Putri, H. T. (2020). Covid 19 dan harga saham perbankan di Indonesia. Eksis: Jurnal Ilmiah Ekonomi Dan Bisnis, 11(1), 6-9. https://doi.org/10.33087/eksis.v11i1.178

K. Ramelli, S., \& Wagner, A. F. (2020). Feverish stock price reactions to COVID-19. Review of Corporate Finance Studies. https://doi.org/10.1093/rcfs/cfaa012

L. Sumiari, K. N., \& Putri, W. T. I. (2020). Reaksi Pasar Terhadap Pengumuman Covid-19 di Indonesia. Jurnal Bisnis Dan Kewirausahaan, 16(2580-5614), 232-236. https://doi.org/10.31940/jbk.v16i3.2081

M. Wenno, M. (2020). Dampak COVID-19 Terhadap Perubahan Harga Saham dan Volume Transaksi (Studi Kasus pada PT. Bank Mandiri. Tbk). Jurnal SOSOQ Nomor 2, 8, 84-91.

N. WHO. (2020). Coronavirus Disease 2019 (COVID-19) World Health Situation Report 1. WHO Indonesia Situation Report, 2019(March), 8.

O. Zhang, D., Hu, M., \& Ji, Q. (2020). Financial markets under the global pandemic of COVID-19. Finance Research Letters. https://doi.org/10.1016/j.frl.2020.101528Zu mla., Chan., Azhar., Hui., Y. (2016). Coronaviruses-drug discovery and therapeutic options. Nature Reviews Drug Discovery. 